\title{
Evaluation of System of Planting with Different Foliar application of Liquid Organic Formulation under Organic Rice [Oryza sativa (L.)] Production
}

\author{
Divyansh Verma* and Thomas Abraham
}

Department of Agronomy, Naini Agricultural Institute, Sam Higginbottom University of Agriculture, Technology \& Sciences, Allahabad-21100, Uttar Pradesh, India

*Corresponding author

\section{A B S T R A C T}

\section{Keywords}

Rice, Liquid organic

formulation, SRI,

Conventional transplanted

rice, Direct seeded rice

Article Info

Accepted:

17 July 2018

Available Online:

10 August 2018
A field experiment was conducted at Shiats Model Organic Farm (SMOF), SHUATS, Allahabad, during the kharif season of 2017 with 18 treatment replication thrice in Split Plot Design, to determine the effect of system of planting and different liquid organic formulation on growth and yield of organic rice (Oryza sativa). The result revealed that SRI system of planting was the best planting system for obtaining maximum number of tillers (10.71), dry weight $(21.67 \mathrm{~g})$, panicle length $(27.13 \mathrm{~cm})$, highest grain yield $\left(2.88 \mathrm{tha}^{-1}\right)$, straw yield $\left(4.11 \mathrm{tha}^{-1}\right)$. Along with foliar spray of sea weed extract.

\section{Introduction}

Rice (Oryza sativa L.) is the most important food crop of India and is a major energy source for about $60 \%$ of the world population. Asia's food security largely depends on the irrigated rice which produces three quarter of total rice production. About $90 \%$ rice is produced and consumed in Asia where the demand for rice is on the rise due to increasing population (Amudha et al., 2009). Rice production under current inputs and technology is likely to fail to meet the projected demand, and there is an urgent need to increase rice productivity in the world. On an average, 2500 liter of water is applied, ranging from 800 to more than 5000 liter, to produce $1 \mathrm{~kg}$ of rough rice (Bouman, 2009). Recently rice cultivation under non-flooded conditions (aerobic) is being considered as an alternative to the conventional rice cultivation system in regions where rainfall and fresh water resources are limited. Under organic production the organic manures like farm yard manure (FYM) and compost are bulky in nature and very laborious to carry in the hilly terrain of north east reason. Availability of adequate quantity of organic manure in time and place is another constraint in crop production. Under such situation, seaweed extract and other liquid organic formulation like panchagavya and fish amino acid can be alternative, being an economic and low volume organic source of fertilizer. Use of 
such organic fertilizers has gained popularity due to their potential use in organic and sustainable agriculture. These organic formulations contain all the trace elements and some essential plant growth hormones (Zhang and Ervin, 2008). Natural plant growth regulators (e.g. Auxin, Gibberellin and cytokinin) present in these liquid organic formulations give a major boost to crop yields by accelerating the plant's metabolic function (Zhang and Ervin 2008).

\section{Materials and Methods}

A field experiment was conducted at Shiats Model Organic Farm (SMOF), SHUATS, Allahabad, during the kharif season of 2017 with 18 treatments, replication thrice in Split Plot Design, under fully organic conditions to evaluate the effect of system of planting and different liquid organic formulation on growth and yield of rice (Oryza sativa).The experiment was laid out in split plot design with 3 planting methods (SRI, Direct Seeded Rice and Conventional Transplanted Rice) and 3 liquid organic formulation [Panchagavya (2 foliar spray at 20 and 40 DAT), Panchagavya (3 foliar spray at 20, 40 and 60 DAT), sea weed extract (2 foliar spray at 20 and 40 DAT), sea weed extract ( 3 foliar spray at 20, 40 and 60 DAT), fish amino acid (2 foliar spray at 20 and $40 \mathrm{DAT}$ ), fish amino acid (3 foliar spray at 20, 40 and 60 DAT)] as subplot treatments with 3 replications.

The recommended dose of fertilizer was taken as $120 \mathrm{~kg} \mathrm{~N} / \mathrm{ha}, 60 \mathrm{~kg} \mathrm{P} / \mathrm{ha}, 40 \mathrm{~kg} \mathrm{~K} / \mathrm{ha}$. However in situ green manure and FYM was applied at the time of final land preparation of sub-plot. $1 \mathrm{~m}^{-2}$ was harvested from every plot for the determination of result and statistical analysis was done using analysis of variance in split-plot design using software and statistical mean differences were found by Fisher's protected least significant difference test.

\section{Results and Discussion}

\section{Growth attributes}

\section{No. of tillers per hill}

The result indicates that significant and maximum number of tillers per hill (10.71) at 75 DAS/DAT was observed under SRI system of planting. However, conventional transplanted rice was found to be statistically at par with SRI system of planting this might be due to planting in square method with wider spacing might have resulted in profused tillering under SRI cultivation which might have facilitated plants for better utilization of the resources. This advantage of SRI method in enhancing tiller numbers has been reported earlier by Udaykumar (2005). While among foliar application of $3 \%$ liquid organic formulation maximum (10.60) number of tillers hill $^{-1}$ was observed 2 foliar spray of fish amino acid (at 20 and 40 DAT/DAS).

\section{Dry matter}

Maximum dry weight (21.67g) was observed in SRI system of planting. Among foliar application treatments maximum value of dry weight $(22.73 \mathrm{~g})$ was found with 3 foliar spray of sea weed extract (at 20, 40 and 60 DAT/DAS).Planting under SRI might have facilitated plants for better utilization of the resources. Further, due to foliar application of sea weed extract, improvement in physiological function of nutrient mobilization and partitioning increased in the dry matter production Zodape et al., (2009) (Table 1).

\section{Leaf Area Index}

Maximum leaf area Index (2.49) was found under conventional transplanted rice and among the foliar applications maximum leaf area (1.90) was found with 3 foliar spray of sea weed extract (at 20, 40 and 60 DAT/DAS). 
Table.1 Effect of system of planting and foliar application of liquid organic formulation on growth attributes of rice at 75 DAS/DAT

\begin{tabular}{|c|c|c|c|}
\hline \multirow[t]{2}{*}{ Factors and Treatment } & \multicolumn{3}{|c|}{ Growth attributes of Rice (at 75 DAS/DAT) } \\
\hline & $\begin{array}{c}\text { No. } \\
\text { of tillers }\end{array}$ & $\begin{array}{c}\text { Plant } \\
\text { dry weight } \\
\left(\mathrm{g} \text { hill }^{-1}\right)\end{array}$ & $\begin{array}{c}\text { Leaf } \\
\text { area index }\end{array}$ \\
\hline \multicolumn{4}{|l|}{ System of Planting } \\
\hline SRI & 10.71 & 21.67 & 1.49 \\
\hline DSR & 9.57 & 20.03 & 1.44 \\
\hline CTR & 10.32 & 21.02 & 2.49 \\
\hline F test & S & S & $\mathrm{S}$ \\
\hline SEm \pm & 0.16 & 0.22 & 0.03 \\
\hline $\mathrm{CD}(\mathrm{P}=\mathbf{0 . 0 5})$ & 0.64 & 0.88 & 0.11 \\
\hline \multicolumn{4}{|l|}{ Foliar Application of 3\% Liquid Organic formulation } \\
\hline Panchagavya (2 Foliar spray at 20 and 40 DAT/DAS) & 9.87 & 19.35 & 1.74 \\
\hline Panchagavya (3 Foliar spray at 20, 40 and 60 DAT/DAS) & 9.93 & 19.76 & 1.76 \\
\hline Sea weed extract ( 2 Foliar spray at 20 and 40 DAT/DAS) & 10.47 & 21.34 & 1.70 \\
\hline Sea weed extract (3 Foliarspray at 20, 40 and 60 DAT/DAS) & 9.89 & 22.73 & 1.90 \\
\hline Fish amino acid (2 Foliar spray at 20 and 40 DAT/DAS) & 10.60 & 20.97 & 1.79 \\
\hline Fish amino acid (3 Foliar spray at 20, 40 and 60 DAT/DAS) & 10.44 & 21.28 & 1.69 \\
\hline F test & NS & S & NS \\
\hline SEm \pm & 0.26 & 0.33 & 0.08 \\
\hline $\mathrm{CD}(\mathrm{P}=0.05)$ & - & 0.97 & - \\
\hline
\end{tabular}

SRI: System of Rice Intensification, CTR: Conventional Transplanted rice, DSP: Direct Seeded Rice 
Table.2 Effect of system of planting and foliar application of liquid organic formulation on yield attributes of rice

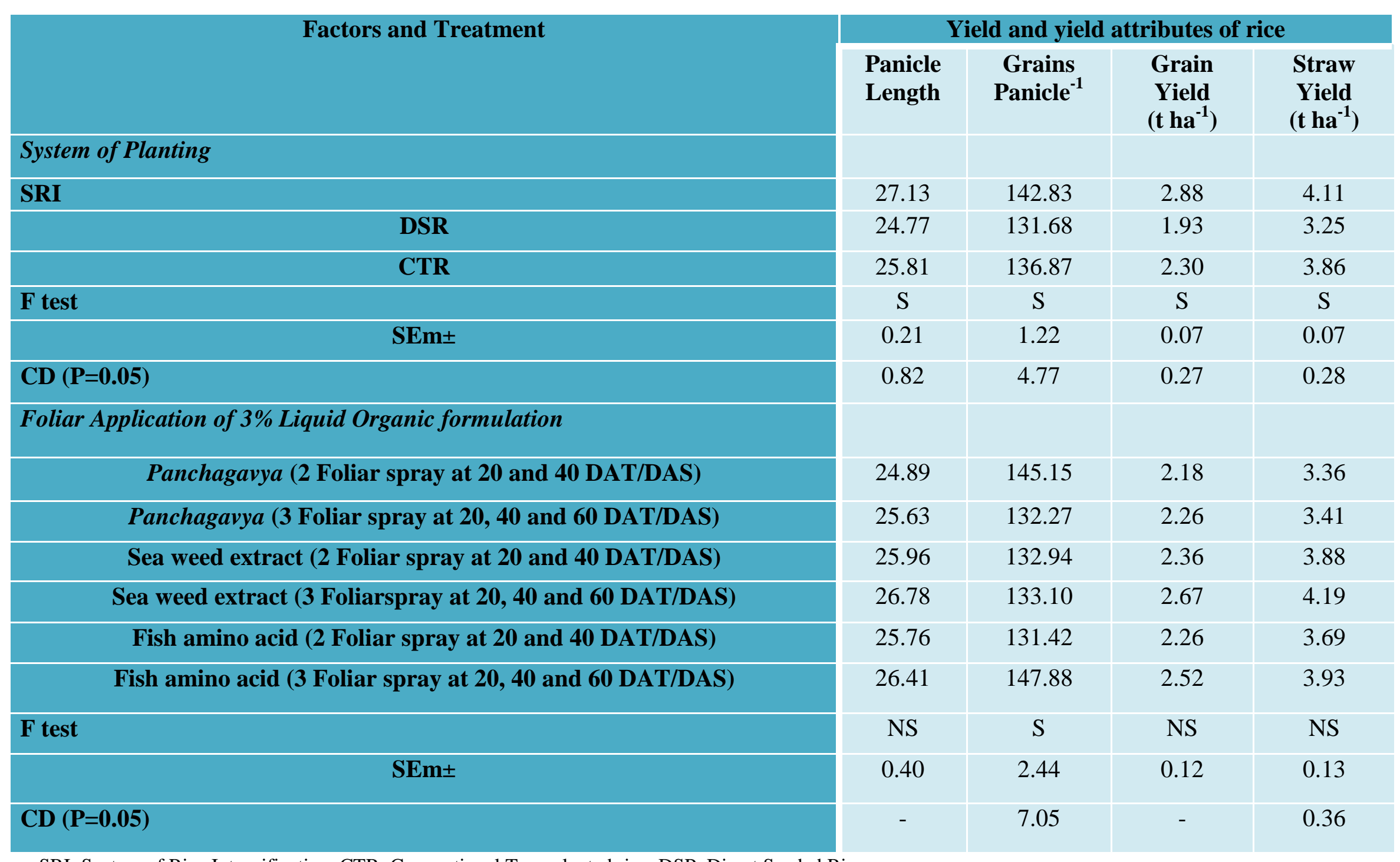

SRI: System of Rice Intensification, CTR: Conventional Transplanted rice, DSP: Direct Seeded Rice 
Thiyagarajan et al., (2002) reported that use of younger seedling do not necessary result in higher leaf area index. Similar tread also found by Anitha and Chellapan (2011). Another reason of maximum LAI due to foliar spray of seaweed extract found by Sivasankari et al., (2006) which might be due to spraying of seaweed extract which was effectively utilized by the crop and expressed in higher LAI.

\section{Yield and yield attributes}

\section{Length of Panicle}

Maximum length of panicle $(27.13 \mathrm{~cm})$ was observed with SRI system of planting. Across foliar applications maximum length of panicle $26.78 \mathrm{~cm}$ was observed with 3 foliar spray of sea weed extract (at 20, 40 and 60 DAT/DAS). Longer panicle in SRI system may be due to the lower rate of leaf senescence in plants that have larger amounts of cytokinins transported into their canopies from the roots (Soejima et al., 1995).

\section{Grains per panicle}

Significant and highest number of grains panicle $^{-1}$ (142.83) was observed in SRI system of planting. Across foliar application maximum number of grains panicle ${ }^{-1}$ (147.88) was found with 3 foliar spray of fish amino acid (at 20, 40 and 60 DAT/DAS). Under SRI cultivation biomass-portioning efficiency increases distinctively, through higher translocation of assimilates, viz., dry matter, carbohydrates, nitrogen, and their conversion rates enhances the grain filling and spike weight in SRI rice (Hugar et al., 2009).

\section{Grain and straw yield}

Maximum grain yield $\left(2.88 \mathrm{t} \mathrm{ha}^{-1}\right)$ and straw yield $\left(4.11 \mathrm{t} \mathrm{ha}^{-1}\right)$ were found under SRI system of planting (Table 2). And among the foliar application of liquid organic formulation 3 foliar spray of sea weed extract (at 20, 40 and 60 DAT/DAS) was recorded maximum values of grain yield $\left(2.67 \mathrm{t} \mathrm{ha}^{-1}\right)$ and straw yield (4.19 $\mathrm{t} \mathrm{ha}^{-}$). Higher grain yield in SRI may have attributed to large root volume, profuse and strong tillers with big panicles, more and well filled spikelets with higher grain weight (Satyanarayana and Babu, 2004) another reason might be due to the fact that seaweed extract is a biostimulant, which provide the rice plant with micro, macro nutrients and significant amounts of cytokinins, auxins and betaines, ultimately increasing the chlorophyll production by boosting the photosynthetic process, thereby stimulating vegetative growth. Thus, an overall plant performance would have been enhanced. Similar findings were observed by Pramnnick et al., (2014).

Based on the current study, it may be concluded that SRI system of planting with 3 foliar spray of sea weed extract (at 20,40 and 60 DAT/DAS)produce highest number of tillers (10.71), highest dry weight (21.67), length of panicle $(27.13 \mathrm{~cm})$, grain per panicle (142.83)grain $\left(2.88 \mathrm{t} \mathrm{ha}^{-1}\right)$, straw yield $(4.11 \mathrm{t}$ $\left.\mathrm{ha}^{-1}\right)$. These findings are based on 1 season, further trials may be required for considering it for recommendation.

\section{References}

Amudha, K., Thiyagarajan, K., Sakthivel, K. (2009) Aerobic rice: a review. Agric Rev 30(2): 145-149.

Anitha, S., and Chellappan, M. 2011. Comparison of the System of rice intensification (SRI), recommended practices, and farmers' method of rice (Oryza sativa L.) production in the humid tropics of Kerala, India. Journal of Tropical Agriculture 49(1-2): 64-71.

Bouman, B. (2009) How much water does rice use? Rice Today 8: 28-29 
Hugar, A. Y., Chandrappa, H., Jayadeva, H. M., Satish, A. and Mallikarjun, G. B. 2009. Comparative performance of different rice establishment methods in Bhadra command area. Karnataka Journal of Agriculture Science. 22(5): 992-994.

Pramanick, B., Brahmachari, K., Ghosh, A. and zodape. 2014. Effect of seaweed saps on growth and yield improvement of Transplanted rice in old alluvial soil of west Bengal, Bangladesh Journal of Botany. 43(1): 53-58.

Satyanarayana, A. and Babu, K.S. 2004. Manual of System of Rice Intensification (SRI), Acharya N. G. Ranga Agriculture University, Hyderabad. (A.P.).

Sivasankari. (2006).Seaweed Resources in Europe: Uses and Potential, 65-81. FAO. Bioresource Technol, 97: 17451751.

Soejima, H., Sugiyama, T. and Ishihara, K. 1995. Changes in the chlorophyll contents of leaves and in levels of cytokinins in root exudates during ripening of rice cultivars Nipponbare and Akenohoshi. Plant Cell Physiology. 36: 1105-1114.

Thiyagarajan, T.M., Velu, V., Ramasamy, S., Durgadevi, D., Govindarajan, K.,
Priyadarshini, R., Sudhalakshmi, C., Senthilkumar, K., Nisha, P.T. Gayathry, G., Hengsdijk, H., and Bindraban, P.S. 2002. Effects of SRI practices on hybrid rice performance in Tamil Nadu, India. Water-wise Rice Production. Proc. Internat. Workshop on Water-Wise Rice Production Bouman, B.A.M., Hengsdijk, H., Hardy, B., Bindraban, P.S., Tuong, T.P., Ladha, J.K. (Eds.), IRRI, Philippines, 119-127.

Udyakumar. 2005. Studies on System of Rice Intensification (SRI) for seed yield and seed quality. M.Sc. (Agri.) Thesis, Acharya N.G. Ranga Agric. Univ., Hyderabad (India).

Zhang, X., Ervin, E. H. (2008) Impact of seaweed extract-based cytokinins and zeatin riboside on creeping bent grass heat tolerance. Crop Science 48: 364370

Zodape, S.T., Mukherjee, S., Reddy, M.P., Chaudhary, D.R. (2009) Effect of Kappaphycus alvarezii (Doty) Doty ex silva. extract on grain quality, yield and some yield components of wheat (Triticum aestivum L.) International Journal of Plant Production 3: 97-101

\section{How to cite this article:}

Divyansh Verma and Thomas Abraham. 2018. Evaluation of System of Planting with Different Foliar application of Liquid Organic Formulation under Organic Rice [Oryza sativa (L.)] Production. Int.J.Curr.Microbiol.App.Sci. 7(08): 3278-3283. doi: https://doi.org/10.20546/ijcmas.2018.708.349 